\title{
PRINOS BASIN - A MODEL FOR OIL EXPLORATION
}

\author{
Proedrou $\mathrm{P}^{1}$ and Papaconstantinou C.M. ${ }^{2}$ \\ ${ }^{1}$ Hellenic Petroleum S.A. Kavala Branch. 56A Omonias str.,65302 Kavala tel.2510836370, fax \\ 2510833578, e-mail pproedrou@ Hellenic-Petroleum.gr \\ ${ }^{2}$ Geotech Ltd, P.O. Box 1431, Perigiali 83 Kavala65201, geores @ otenet.gr
}

\begin{abstract}
An extentional tectonic led to the formation of the basin along marginal listric faults. The fast subsidence created the frame for the accumulation of a thick section of miocene, pliocene and quaternary deposits amounted to 5000 meters and resulted to the good preservation of the organic matter as source for the oil generation. The existence of anticlines and other types of traps around the deepest part of the basin where the oil generation took place is another important factor for discovering hydrocarbons. The growth fault activation led to the formation of roll over anticlines in front of them. Stratigraphic oil bearing traps do also exist. The thick salt layers that were deposited during the upper miocene following the isolation of the basin from the open sea contributed to the reduction conditions in it. Moreover this salt cap rock holds the whole oil migration below it and prescribes the stratigraphic level for the prospects. The short distance between the generation area and the surrounded fault and statigraphic traps accelerated the migration and trapping of the hydrocarbons. The strong relief of the basin due to the fast subsidence led to the extend deposition of turbiditic sediments that form the reservoirs for the majority of the fields. The good knowledge of the geological evolution of the basin and the geochemical processes which take place states the best prepositions for a successful hydrocarbons exploration.
\end{abstract}

\section{INTRODUCTION (MAIN $1^{\text {ST }}$ ORDER HEADING)}

The Prinos basin is the only geological area in Greece, where oil and gas are being produced for more than twenty years. Exploration for hydrocarbons in this particular offshore area has started in the beginning of the seventies. The first seismic campaign took place in the sea of Thrace in 1970 and the first oil discovery in Prinos basin occured in 1973. The search for oil in this basin is still under continuation. The largest part of the basin is located offshore between the island of Thassos and the opposite mainland to the west. Only the northeastern portion of it lies onshore in the Delta Nestos plain (Fig. 1). The total area covers $800 \mathrm{~km}^{2}$. The sea depth doesn't exceed fifty meters.

In this presentation it will be attempted to give the general geologic and geotectonic characteristics of Prinos basin, in the wide geological area, while the main effort will be addressed predominantly to the internal evolution of this taphrogenetic basin. Tectonics, paleogeography, sedimentology, petrography, oil generation and migration are discussed separately and lead towards the synthesis of the basin development.

\section{GEOLOGY}

The taphrogenetic Prinos basin is located at the southern edge of the pre-alpidic Rhodope massiv. It remained above the sea level during the Tethys-cycle and only during the middle Miocene started subsiding as a result of the pull-apart postalpidic tectonics that led to the breaking of the Aegean plate. The strike slip faulting of the North Aegean sea left untouched the Prinos basin and the adjacent miocene basins. The vertical pull-apart gravity tectonics is the dominant factor in the formation and development of these basins. 


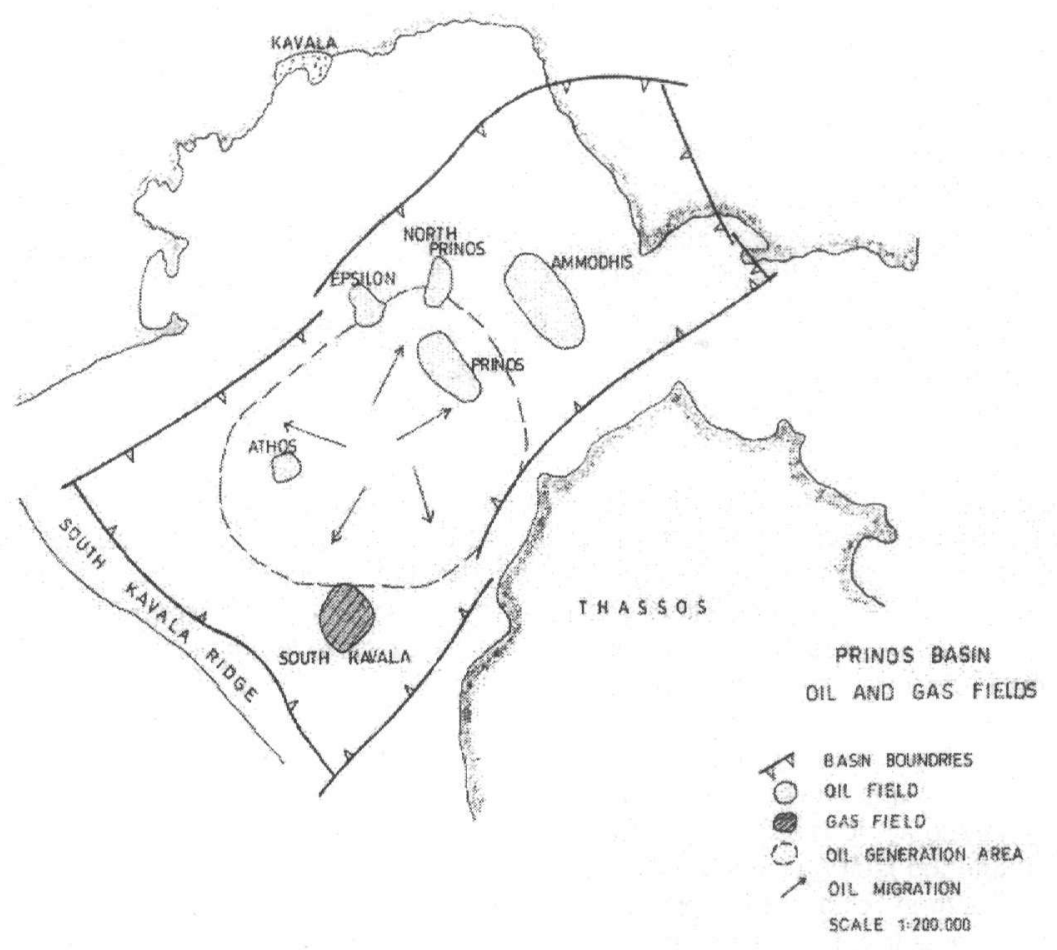

Fig. 1 Oil and gas fields in Prinos basin. Note the oil generation area and the migration paths.

Marginal, long - extented and of large scale gravity faults of various angles surround the basin in NE-SW and NW-SE direction from the Nestos delta in the north to the South Kavala ridge in the south (Fig.1).

These faults, very often in echelon form, led to the taphrogenetic evolution of the Prinos basin. Many of them are active still today. Major internal faults, striking mainly northwest - southeast cross the basin and initiate the trapping mechanism.

Rollover - type anticlines are formed syngenetically in front of these faults (Fig. 2). The anticline formation goes hand in hand with the sedimentation and occupies a large lithological section. Marginal faults in similar directions are also in a few cases leading to the formation of roll - over structures. Pinch out traps to the basin flanks are very often.

The taphrogenetic Prinos basin with a length of $38 \mathrm{~km}$ and a width of approximately $20 \mathrm{~km}$ between the islands of Thassos and Thassopoula and the mainland, is subdivided into two subbasins separated by a topographic basement High located in the Ammodhis area (Proedrou 1979). The northern part forms the Nestos sub-basin and the southern, the most deep, the Prinos sub-basin. Along the southern front of this High has developed with prograding sedimentation a system of NW-SE parallel striking faults dipping southwards to the basin center following the topographic relief. Additional sliding movements assisted by the salt deposition complicated further this area. A such sliding fault underlies the Prinos field along the basal salt and moved the overlied formation to the south forming the broad North Prinos 1 anticline (Fig. 2). In this densely faulted area the majority of the Prinos traps is bound as rollover anticlines in front of syngenetic faults. Typical example is the Prinos field. The Epsilon and Ammodhis anticlines belong to the same classification. The South Kavala field in the south and the Nestos structure in the north are also dome-like anticlines in front of the marginal faults. The activation of the faults goes hand by hand with the sedimentation and their down thrown movement continues until recently. Their prints in the sea ground can be traced in the seismic sections. Due to the flank steepness sliding events take place very often. A broad mainly $E-W$ fault with a displacement of few decades to a few hundred meters crosses the basin in 
the southern part and leads to the formation of the peculiar fault trap of Kallirachi in conjunction with the NE-SW directed marginal fault (Fig. 3).

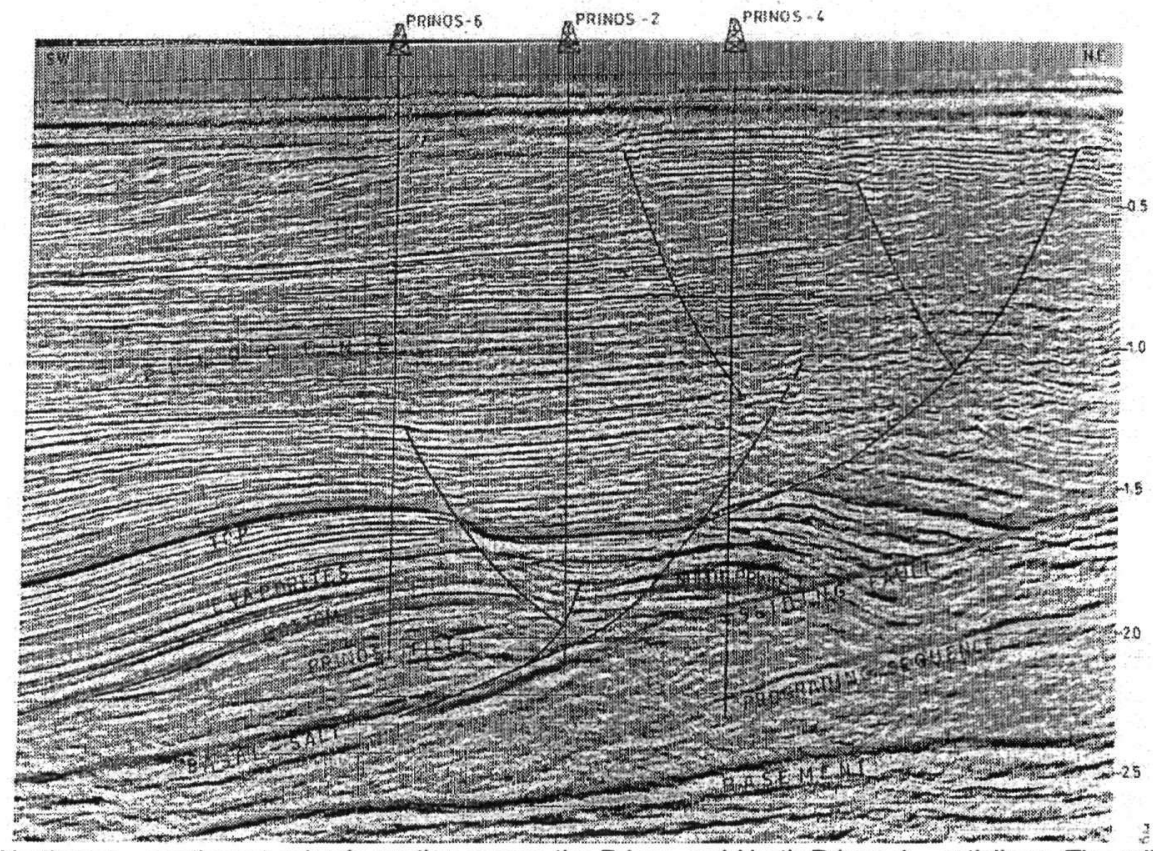

Fig.2 Northeast - southwest seismic section across the Prinos and North Prinos 1 anticlines. The rollover of the seismic horizons in front of the faults is well illustrated.

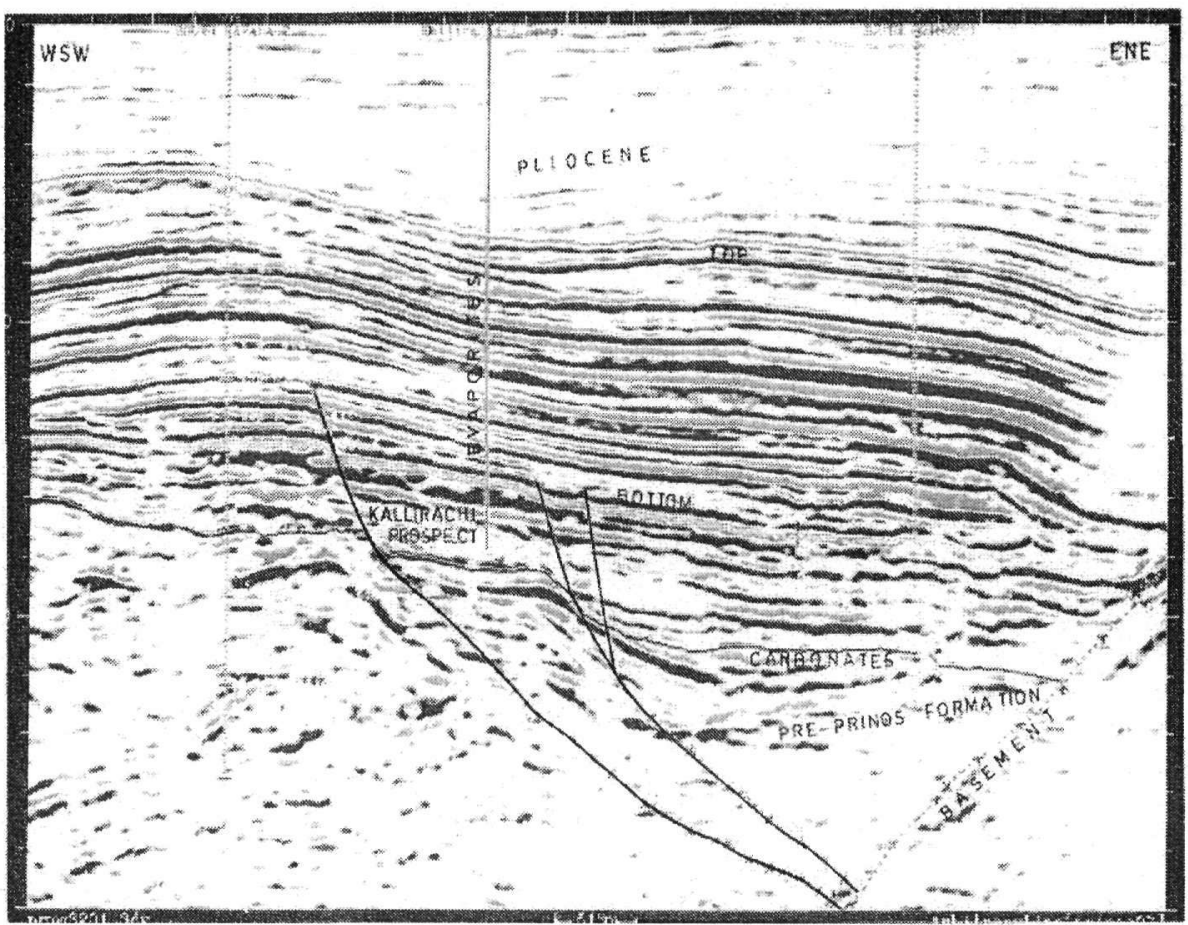

Fig.3 East-northeast / west-south-west seismic section across the Kallirahi prospect. (by Geus). 
The Prinos basin was open to the south to the open sea at the first stage of sedimentation. Gradually the Kavala ridge, a basement high between the island Thassos and the opposite mainland, started to arise and led to the isolation from the sea and the transformation of the basin to a lagune in the messinian time. Similar the ridge, where the small island Thassopoula is sitting, in the northeast side, more probably was part time closed and participated to the full isolation of the basin. By that time a system of land-locked basins was developed in the North Aegean Sea (Proedrou 1979). It is very important to emphasize that all to Prinos adjacent neogene basins have similar to it geological evolution and consequently are the subject of high exploration interest.

\section{STRATIGRAPHY}

The stratigraphic column was already established after completion of the first few wells. Three main series dominate throughout the basin with very distinct boundaries between them (Pollack 1979, Proedrou 1979). They are:

- The Pre - evaporitic Serie

- The Evaporitic Serie

- The Post - evaporitic Serie

They represent different sedimentological environments and normally their thickness increases towards the center of the subbasins. The basement consists of metamorphic rocks mainly gneiss, quartzite and dolomitic marble. The pre-evaporitic series starts with the break up of the basin with the basal sediments and terminates just before the deposition of the main evaporite bodies (Fig.4). The first deposits are of continental character, conglomerates with large basement components, sandstones, feldspatic, mainly immature, claystones and thick coal seams. According to the seismic interpretation these continental deposits were transported from northeast and southwest and moved with diminished thickness towards the center of the subbasins. The total section of the clastic deposits of the pre-evaporitic serie is becoming very thick towards the basin center. The youngest of them have marine character and are mainly shales with sandstone intercalations getting coarser at the periphery of the basin. They overlay the older ones with an unconformity. The above mentioned units are followed by a zone of limestone, dolomite and anhydrite layers alternated with clastics that cover the southern part of the Prinos - subbasin. Towards the center, to the most deep part of the basin, the anhydrite is replaced by salt layers, usually a few meters thick.

At the top of the pre-evaporitic series an extented dark gray claystone deposition, characterized as zone D, dominates all over the southern sub-basin. It is petroliferous and strong carbonaceous. Sandstone intercalations are very often. Turbidite events of huge mass movement took place during that time and interrupted the still deposition mainly in the upper part of this zone. The Prinos turbidite $(300 \mathrm{~m}$ thick ) is the most characteristic example. Equivalent to this zone is the prodeltaic zone of varves in the Nestos area.

The overlying evaporitic series is characterized by two facies. In the northern subbasin anhydrite and limestone layers 3 to 5 meters thick alternate with each other and with sandstones, claystones and marls. In the south seven to eight salt layers with increasing thickness towards the base of the section alternating with clastics comprise this serie with total thickness up to 800 meters (Fig.4) The salt is white, gray, crystalline and often intergrown with anhydrite. Anhydrite and dolomite layers are often intercalated in this serie. Postdiagenetic anhydrite nodules appear very often in the claystones.

The thoroughly clastic post-evaporitic series is characterized by the abundance of foraminifere, nannoplactons and rests of algae that postulate a marine origin of Pliocene age. Towards the top coarse clastic sediments with abundant rests of molluscs point out to a deltaic, according the seismic, prograding sequence. Marine clastic sediments transgrate again over these deposits.

\section{TRAPS AND RESERVOIRS}

The most typical anticlines for the broad basin are the Prinos and Prinos North oil fields as rollover anticlines in front of syngenetic northwest- southeast striking downthrown faults (Fig.2). To 
the same case belongs the south Kavala gas field being formed as a combination of a rollover anticline and a stratigraphic pinch-out of the south western flank against the basement ( $P$. Proedrou 2001). In contrast, the Ammodhis structures, as well as the Epsilon structure are rollover anticlines surrounded by mainly down-thrown faults. Stratigraphic traps are traced along the basin margins and mainly along the western margin, where the basin flank is dipping gently. A peculiarity states the Kallirachi trap building up between two major down-thrown faults in conjunction. The first fault is marginal and syngenetic with the basin formation, while the second one as internal fault, is postdepositional. The stratigraphic horizons are dipping from the fault conjunction to the centre of the basin (Fig. 3).

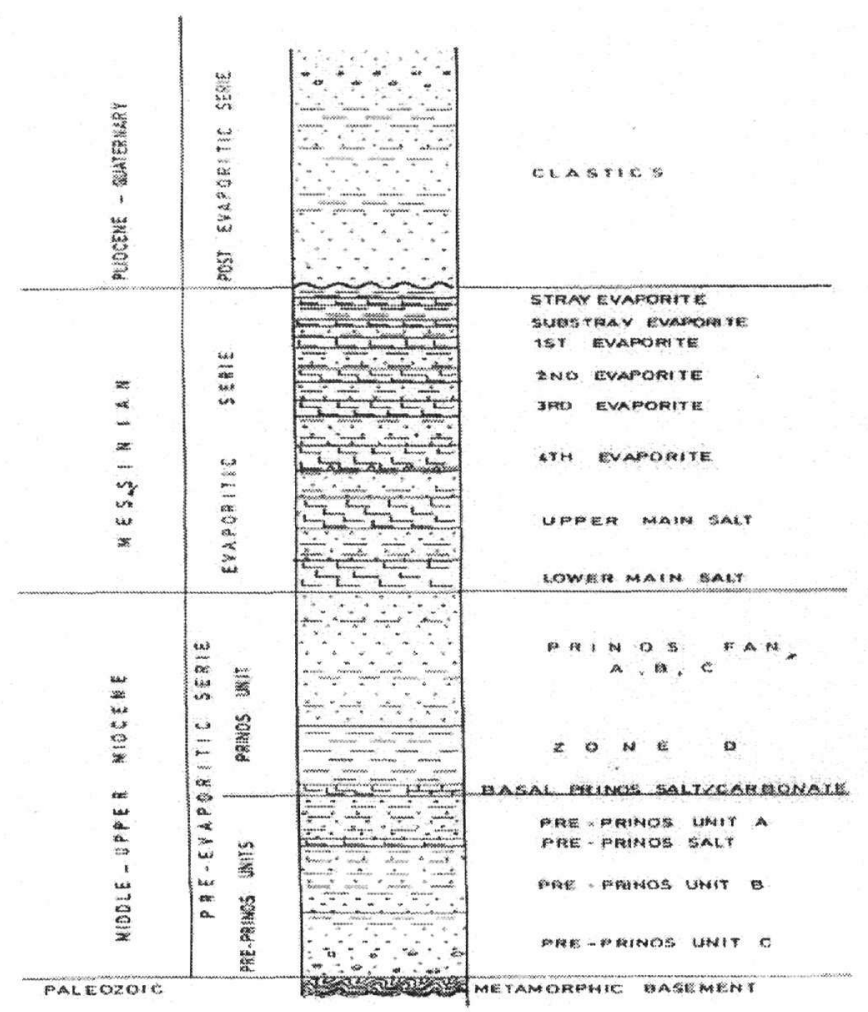

Fig. 4 Chronostratigraphic column of the Prinos basin.

Sandstones and in minor degree siltstones compose the reservoirs. The depositional environment is deltaic, marine and turbiditic. But in the stratigraphic intervals where the oil has been trapped just below the evaporites or between them the depositional model is of turbiditic nature. The fast subsidence of the basin created a steep relief that led to the sediment movement from the flanks to the basin centre or along its axis from areas topographically higher to the lower ones. The turbiditic nature is a very common type of sedimentation.

The evaporite horizons cover the whole basin and hold the upwards hydrocarbon movement below them. Exception states the gas accummulation in South Kavala field. It is thought that the gas had escaped due to its mobility during a fault activation that pinches out in the Upper Main Salt and was trapped between it and the $4^{\text {th }}$ Evaporite (Fig.3). The thin anhydrite and limestone beds of the evaporitic zone in the northern half of the basin remain open after fault movement and allow the dispersion of light hydrocarbons to the surface as in the case of Ammodhis field.

The turbiditic reservoirs were the subject of detailed petrographic and sedimentological studies before the development of the fields. The $A 4 / B 2, C, D$ and $E$ facies were recognized according 
to the turbidite facies classification. The A4/B2 facies provides the best reservoir quality representing channel deposits with high porosities and permeabilities. The $\mathrm{C}$ face still provides good permeable reservoirs as front channel deposits. In opposite, E and D facies represent interchannel and distal deposits and consist mainly of claystones with thin sandstone intercalations forming reservoirs of low to very low quality. Breccia in a shaly matrix are quite common in the South Kavala field.

Porosities and permeabilities are generally decreasing with increasing depth due to compaction, clay content and dolomitisation. There is a rapid decrease in the porosity and permeability parameters below the oil - water contact due to the dolomitisation that took place after the oil migration and was influenced by the formation water (Proedrou @ Sidiropoulos 1992).

\section{OIL GENERATION AND MIGRATION}

Marine claystones of Middle to Upper Miocene age and messinian claystones deposited under highly reducing conditions interrupted by hyperjaline episodes are considered to be the source of oil in the basin. Coal deposits may have a good potential for gas generation. The oil source - rock is characterized by a waxy sapropelic oil prone kerogen with terrestrially derived organic matter frequently dominant. It belongs to the types I and III of kerogen composition. TOC values vary from 1.20 to $3.90 \%$ and the $\mathrm{HI}$ from 100 to $500 \mathrm{mg} \mathrm{HC} / \mathrm{g}$ to TOC. For the Nestos area the equivalent TOC values vary between 0.5 and 1.7 and are mainly gas prone. Maturity measurements show vitrinite reflectance up to 1.10 for depths up to 3500 meters. The central part of the basin, with a depth of approximately $5500 \mathrm{~m}$ was never reached by drilling. In Nestos area the vitrinite reflectance reaches up to 1.87 at depth of $3950 \mathrm{~m}$ closed to the basement. Generally there is a rapid increase of thermal maturity towards the basement throughout the basin suggesting that a heat source is originating from it (Robertson Research INT. 1981).

According to the oil maturation plots oil reached the threshold of maturity during latest Miocene in the deepest part of the basin. Generation continued throughout the Pliocene and recent. The present top of the maturation window starts at depths of $2500 \mathrm{~m}$ corresponding to a vitrinite reflectance value of 0.55 . The equivalent top for gas window is at depth of $4000 \mathrm{~m}$ (Proedrou, @ Sidiropoulos 1992). Only in Nestos area where the geothermal gradient is very high the zone of peak gas generation is reached at $3500 \mathrm{~m}$. The Prinos, North Prinos, Epsilon and Ammodhis oils are of the same quality. They belong to an aromatic - asphaltic type with a sulfur content. The gases are dissolved in the wet phase and consist from methane to pentane with $\mathrm{H} 2 \mathrm{~S}$ and $\mathrm{CO} 2$ in various percentages. Free of $\mathrm{H} 2 \mathrm{~S}$ is the Athos oil. The South Kavala gas that contains condensate and the Nestos gases are also free of $\mathrm{H} 2 \mathrm{~S}$ and $\mathrm{Co}$. The most sensible explanation for the different oil quality has to be found in the different source rock types that were deposited in the basin. The sweet hydrocarbons more probably have been generated from the earlier deposited miocene claystones in an open marine phase. This early phase produced more mature hydrocarbons without any $\mathrm{H}_{2} \mathrm{~S}$ contribution. The coal has more probably also contributed to the gas generation. In contrast the Prinos, North Prinos, Epsilon and Ammodhis fields contain a more immature oil with high content in $\mathrm{H} 2 \mathrm{~S}$ and $\mathrm{CO} 2$ that mainly was originated from the under reducing conditions deposited claystones (Rigakis et al 2001). The very low API which characterizes the Ammodhis oil is the result of the light hydrocarbons leakage through the faults to the surface.

Concerning the oii migration it breaks out from the deepest parts of the southern half of the basin and spreads out radial to the periphery and to the central basin Highs where the trapping mechanisms were present (Fig. 1). The gas migration from the deepest part of the Nestos subbasin is very local and due to the absence of good quality and sufficient volume reservoirs has been dispersed.

\section{EXPLORATION CONCEPT}

A small basin of such a young age can generate enormous quantities of hydrocarbons". This is the main conclusion that can be drawn from the long time exploration and production activity in the Prinos basin. This of neogene age taphrogenetic basin combines all the prepositions for oil generation, migration and accumulation in the trapping mechanisms. 
The fast subsidence of this taphrogenetic basin created the frame for the accumulation of such a thick section of neogene and quaternary deposits and led to the extend deposition of turbiditic sediments and the good preservation of the organic matter as source for the oil generation. The existence of a good and thick salt cap rock holds the whole oil migration below it and prescribes the stratigraphic modeling of the prospects. The oil migration in the southern part of the basin reached up to the margins.

The growth fault tectonism led to the formation of the rollover anticlines, as trapping mechanism, all of them around the central deepest part of the basin where the main oil generation took place. The migration paths are consequently few kilometers long. The 3-D seismic helps to map the most complicated structures but it helps little locating the reservoirs. It is the task of the geological science to create the sedimentological models and locate the reservoir targets. The tracing of the turbidities for the location of reservoirs is the most difficult task in this basin.

Searching further for hydrocarbons the exploration is directed to any type of trapping located at the base of the evaporitic zone. Well sealed traps containing a sufficient permeable reservoir section are promising for more discoveries in an oil mature basin. This for Prinos basin established model should be considered as a guide in the exploration of the neogene basins in the Northern Aegean Sea with similar geological and geochemical evolution to that of Prinos.

\section{REFERENCES}

Georgakopoulos A. 1998. Lithology and Stratigraphy of the Neogene Prinos-KavalaBasin, Northern Greece: Geological Society of Greece, Special Publications, No 9.79-84.2000

Pollak, W.H. 1979. Structural and lithological development of the Prinos-Kavala basin, Sea of Thrace, Greece: Athens, Aannex Geologique Pays Hellenic tome hors serie, fash II, p. 1003-1011, Vith International Congress on Mediterranean Neogene.

Proedrou P. 2001. South Kavala gas field -Taphrogenetic Prinos basin: Athens, $9^{\text {th }}$ International Congress of the Geological Society of Greece, Volume XXXIV, No 3. P. 1221-1228.

Proedrou P. @ Sidiropoulos Th. 1992. Prinos field -Greece, Aegean basin, structural traps: Treatise of petroleum Geology, atlas of oil and gas fields, AAPG,p 275-291

Proedrou P. 1979. The evaporite formation in the Nestos - Prinos graben in the Northern Aegean Sea: Annex Geologique Pays Hellenic, tome hors serie fash II,P.1013-1020, Athens.

Rigakis N. et al. 2001. Hydrocarbon gas accumulation in Greece and their origin. $9^{\text {th- }}$ International Congress of the Geological Society of Greece . Volume XXIV, No 3, R 1265-1273, Athens.

Robertson Research International Ltd. 1981. Geological studies of five wells from the Prinos field, north Aegean Sea: Report No 531p/c, Volume I, internal report, North Aegean Petroleum Company, Athens. 